\title{
公益社団法人日本地震工学会
}

\section{首都直下地震の 被害想定とその課題}

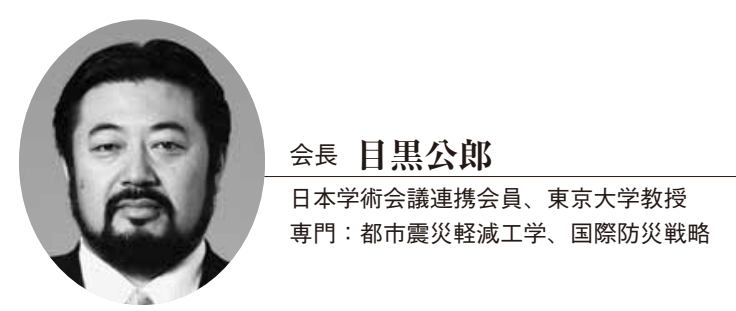

首都直下地震による被害像：東京都をはじめと する首都圈の自治体や政府中央防災会議が首都 直下地震による被害想定を行っているが、被害 の全体像は中央防災会議による推定結果が分か りやすい。中央防桨会議は、30年以内に $70 \%$ の 確率で起きるとされるマグニチュード（M）7 級の19パターンの地震に加え、当面の発生確率 は低いが長期的な対策の対象としてM8級の2パ ターンの地震も想定している。被害の規模は、 発生確率の高いM7級の地震を対象とすると、 被害が最大となる都心南部直下地震の場合に、 被害総額は95.3兆円（資産損失47.4兆円＋経済 活動への影響47.9兆円）、建物被害は「冬・夕 方・風速 $8 \mathrm{~m} 」$ の最悪ケースで、全壊・全焼棟 数が摇れによる約 17.5 万棟や延焼火災による約 41.2 万棟を含めた総数で約 61 万棟、死者数は建 物被害による約 6,400 人や延焼火災による約 1.6 万人を含めて約 2.3 万人なっている。

被害想定の手法：被害想定は一般に次のような 流れで行われる。a）対象地域に起こる可能性 の高い地震（これをシナリオ地震という）を選 定し、この地震の場所と大きさ（詳細検討の際 には断層の角度や破壊の開始点、進展方向など も）を決める。対象地域の位置と地形や表層地 盤の特性を考慮して、b）各地を襲う地震動の 特性（強さと周波数特性）を求める。c）各地 に存在する社会インフラや住宅をはじめとする 構造物の強度特性とb）で求めた地震動を、被 害関数を介して比較することで各種の物理的な 被害量（直接被害ともいう）を評価する。d） 次に、c）で求めた被害量を基に、発災時刻や
気候条件などを加味した上で、出火・延焼件数 や人的被害、さらには経済的な被害（間接被害 という）を評価する。

被害想定の課題：現在の最重要課題は「被害 想定の目的化」である。「被害想定を何度やっ ても、評価式の精度をどれだけ上げても、被害 は全く減らない」ことを再認識すべきである。 被害は具体的な対策の実施によってのみ軽減さ れ、被害想定はこれを効率化する情報の入手手 段でしかない。また、用いる断層モデルや地質 ／地盤データ、被害関数などに不確定な要素が 多いので、結果の精度は一般に高くない。ゆえ に研究成果としての評価手法の高度化がもたら す想定被害の変化に一喜一憂する意味もない。 同一の評価手法で定期的に確認し、経年による 地域の変化や実施した対策の効果を評価するこ とが重要だ。また防災戦略のツールとして被害 想定を位置付けた場合、従来のブラックボック ス的評価ではなく、「誰が、何をすれば、どん な被害が、どう変化するのか」の因果関係が見 える評価、すなわち努力の効果が見える評価へ と変えるべきだ。

想定する被害項目に関しては、従来はライフ ラインの復旧予想などを除いて、発災直後の被 害を見積もることに主眼が置かれていた。今後 は、直後のみならず被害の進展プロセスまでを、 想定の対象に拡大していくべきだ。その際には、 事前対策によって変化する被害の評価に基づく 事後対応時の業務量やタイミングも評価し、事 前から復旧・復興までの総合的な災害マネジメ ントに貢献する情報提供が求められる。 